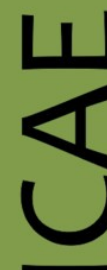

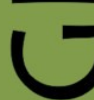

ex Instituto Archaeologico Universitatis de Rolando Eötvös nominatae

O

$\overrightarrow{0}$

山

$\leftarrow$

I

$\cup$

ه

$\leftarrow$

u

Ш

Z

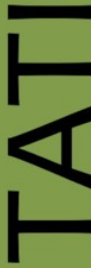

œ

ш

n

n

$\varnothing$
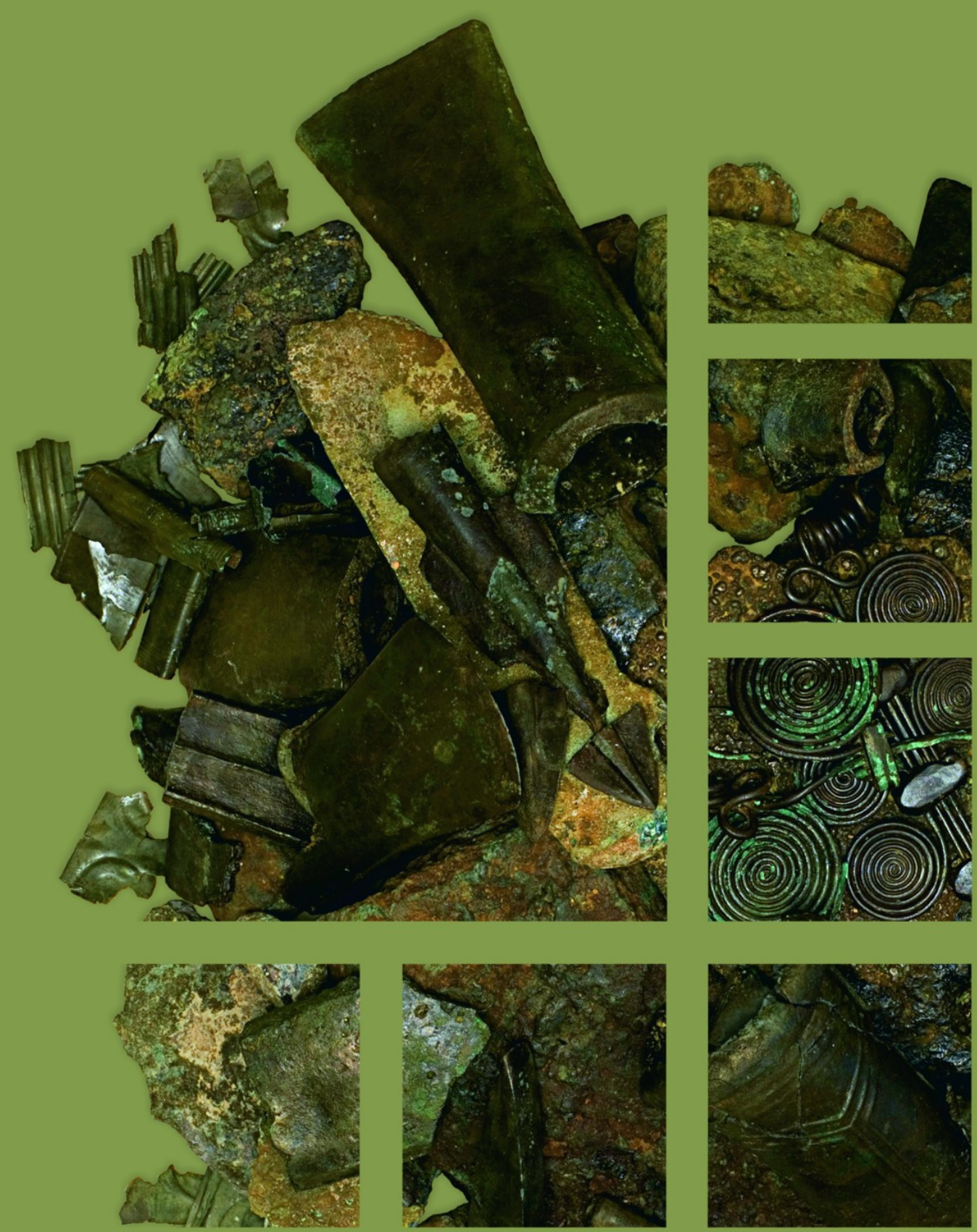


\section{Dissertationes Archaeologicae ex Instituto Archaeologico}

Universitatis de Rolando Eötvös nominatae Ser. 3. No. 2.

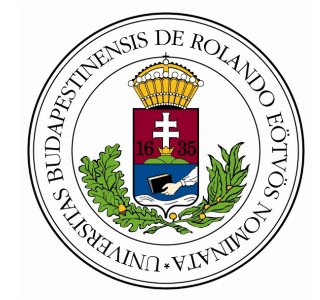

Budapest 2014 
Dissertationes Archaeologicae ex Instituto Archaeologico Universitatis de Rolando Eötvös nominatae

Ser. 3. No. 2.

Editor-in-chief:

DÁvid BARTus

Editorial board:

LÁsZló BARTOSIEWICZ

LÁSZLÓ BORHY

IsTVÁN FELD

GÁBOR KALLA

PÁL RACZKY

MiKLÓs SzABÓ

TIVADAR VIDA

Technical editors:

DÁvid BARTus

GÁBOR VÁCZI

ANDRÁs BÖDŐCS

DÁNIEL SZABÓ

Proofreading:

SZILVIA SzÖLLősI

Available online at http://dissarch.elte.hu Contact: dissarch@btk.elte.hu

$$
\begin{aligned}
& \text { PUBLIC } \\
& \text { KNOWLEDGE } \\
& \text { PROJECT }
\end{aligned}
$$

(c) Eötvös Loránd University, Institute of Archaeological Sciences

Budapest 2014 


\section{Contents}

\section{SElected PAPERS OF THE XI. Hungarian CONFERENCE on Classical Studies}

Ferenc BARNA

Venus mit Waffen. Die Darstellungen und die Rolle der Göttin in der Münzpropaganda

der Zeit der Soldatenkaiser (235-284 n. Chr.)

Dénes GABLER

A belsó vámok szerepe a rajnai és a dunai provinciák importált kerámiaspektrumában

Lajos MATHÉDESZ

Római bélyeges téglák a komáromi Duna Menti Múzeum gyújteményében

Katalin OtTOMÁNYI

Újabb római vicusok Aquincum territoriumán

Eszter SÜVEGH

Hellenistic grotesque terracotta figurines. Problems of iconographical interpretation

András SzABó

Some notes on the rings with sacred inscriptions from Pannonia

István VIDA

The coinage of Flavia Maxima Helena

\section{Articles}

Gábor TARBAY

Late Bronze Age depot from the foothills of the Pilis Mountains

Csilla SÁRó

Roman brooches from Paks-Gyapa - Rosti-puszta

András BöDőcs - Gábor KovÁcs - Krisztián ANDERKó

The impact of the roman agriculture on the territory of Savaria

Lajos JuHÁsz

Two new Roman bronzes with Suebian nodus from Brigetio

\section{FIELD REPORTS}

Zsolt MESTER - Norbert FARAGó - Attila KirÁLy

The first in situ Old Stone Age assemblage from the Rába Valley, Northwestern Hungary

Pál RACZky - Alexandra ANDERs - Norbert FARAgó - Gábor MÁRKus

Short report on the 2014 excavations at Polgár-Csőszhalom 
Preliminary Report on the first season of fieldwork in Berettyóúffalu-Szilhalom

Márton SzILÁgyi - András FüZESI - Attila VIRÁG - Mihály GASPARIK

A Palaeolithic mammoth bone deposit and a Late Copper Age Baden settlement and enclosure

Preliminary report on the rescue excavation at Szurdokpüspöki - Hosszú-dúlö II-III. (M21 site No. 6-7)

Kristóf FüLÖP - Gábor VÁcZI

Preliminary report on the excavation of a new Late Bronze Age cemetery

from fobbágyi (North Hungary)

Lőrinc TimÁr - Zoltán CzAJLik - András BöDőcs - Sándor PuszTA

Geophysical prospection on the Pâture du Couvent (Bibracte, France). The campaign of 2014

Dávid BARtus - László Borhy - Gabriella Delbó - Emese SzÁmadó

Short report on the excavations in the civil town of Brigetio (Szőny-Vásártér) in 2014

Dávid BARTus - László BorHy - Emese SzÁMADó

A new Roman bath in the canabae of Brigetio

Short report on the excavations at the site Szőny-Dunapart in 2014

Dávid BARTus - László Borhy - Zoltán CzAjlik - Balázs Holl -

Sándor PuszTA - László RuPNiK

Topographical research in the canabae of Brigetio in 2014

Zoltán CZAJLIK - Sándor BERECKI - László RUPNIK

Aerial Geoarchaeological Survey in the Valleys of the Mureș and Arieș Rivers (2009-2013)

Maxim MoRDovin

Short report on the excavations in 2014 of the Department of Hungarian Medieval

and Early Modern Archaeology (Eötvös Loránd University, Budapest)

Excavations at Castles Čabrad' and Drégely, and at the Pauline Friary at Sáska

\section{Thesis Abstracts}

Piroska Csengeri

Late groups of the Alföld Linear Pottery culture in north-eastern Hungary

New results of the research in Borsod-Abaúj-Zemplén County

Ádám Bíró

Weapons in the 10-11th century Carpathian Basin

Studies in weapon technology and methodology - rigid bow applications and southern import

swords in the archaeological material

Márta DARÓcZI-SzABó

Animal remains from the mid 12th-13th century (Árpád Period) village of Kána, Hungary

Károly BELÉNYESY

A 15th-16th century cannon foundry workshop in Buda

Craftsmen and technology of cannon moulding and the transformation of military technology

from the Renaissance to the Post Medieval Period 
István RINGER

Manorial and urban manufactories in the 17th century in Sárospatak

\section{BIBLIOGRAPHY}

László BORHY

565

Bibliography of the excavations in Brigetio (1992-2014) 


\title{
Hellenistic grotesque terracotta figurines Problems of iconographical interpretation
}

\author{
ESZTER SÜVEGH \\ Institute of Archaeological Sciences \\ Eötvös Loránd University \\ suvegh_eszter@hotmail.com
}

\begin{abstract}
In the study of grotesque terracotta statuettes from the Hellenistic Age many questions are yet to be answered, including the 'identity' of these figurines. This article aims at giving reference points for the iconographical interpretation of the grotesques. In the first part of the article I collected some circumstances hindering the decipherment of the grotesque terracottas. Then, as the majority of these objects are head fragments broken from the bodies of statuettes, I tried to present details and attributes that may hint at the original meaning of the figurines, even without any knowledge of the missing parts of their bodies. These details include hairstyle and headwear, facial features typical of certain ethnic groups, signs of pathologies, characteristic injuries and features known from the sphere of the theatre.
\end{abstract}

Within the vast material of figural terracottas of the Hellenistic Age - alongside the many idealizing types - it is customary to label with the term 'grotesque' those human figures which were not produced to depict perfection; instead, their creator aimed at reflecting reality, or rather an exaggerated, misshapen form thereof. However, these grotesques do not constitute as uniform a group as the modern collective term seems to suggest. If one tries to identify these figurines more specifically, one has to begin the search in more than one direction in order to reach an iconographical interpretation, because the exaggerated, ugly physical features common to all statuettes can be explained in different ways in individual cases. ${ }^{1}$ This article intends to present some reference points at our disposal in this process, through the example of some of the grotesque terracotta statuettes in the Collection of Classical Antiquities of the Museum of Fine Arts, Budapest.

Primarily we have to mention some circumstances that make the task of interpreting the figurines quite difficult. One of the essential problems is that in most cases we lack information concerning the findspots of the grotesques: these artefacts mainly found their way into today's museum collections through art dealers and were presumably unearthed at illegal excavations carried out from the end of the 19th century onwards. ${ }^{2}$ Among the assumed findspots the two most important sites are ancient Smyrna and other centres of Asia Minor as well as Egypt, more specifically Alexandria. ${ }^{3}$

In addition, the fragmentary condition of these small-scale sculptures also presents difficulties, as the majority of the objects acquired by different museums are heads broken from the

1 Rumscheid 2006, 291; Fischer 1994, 51, 70; BURN - Higgins 2001, 128.

2 BURn - Higgins 2001, 127.

3 Higgins 1967, 112. 
bodies or less often limbless torsos of the statuettes. ${ }^{4}$ It is obviously more difficult to decipher the original meaning of the grotesque terracottas based merely on these fragments, especially, if we also take into account the production techniques used by the coroplasts of the Hellenistic Age.

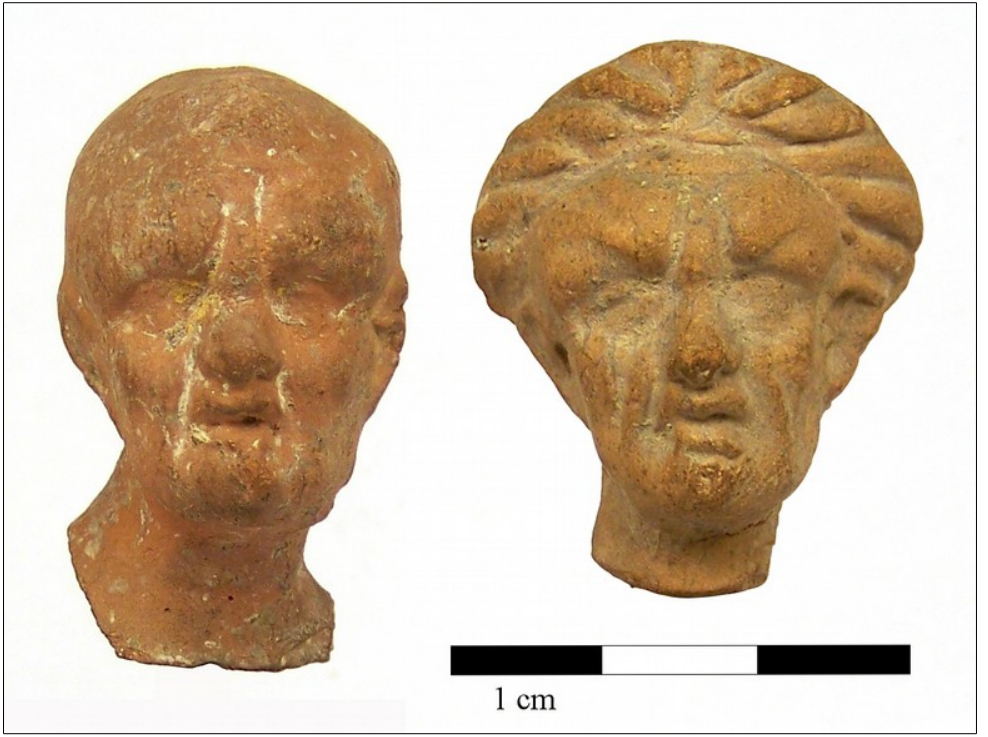

Fig.1. Head of a bald man (inv. nr. T.385) and the same type transformed into an old woman (inv. nr. T.426), earrings now missing (Museum of Fine Arts, Budapest, photo: E. Süvegh).

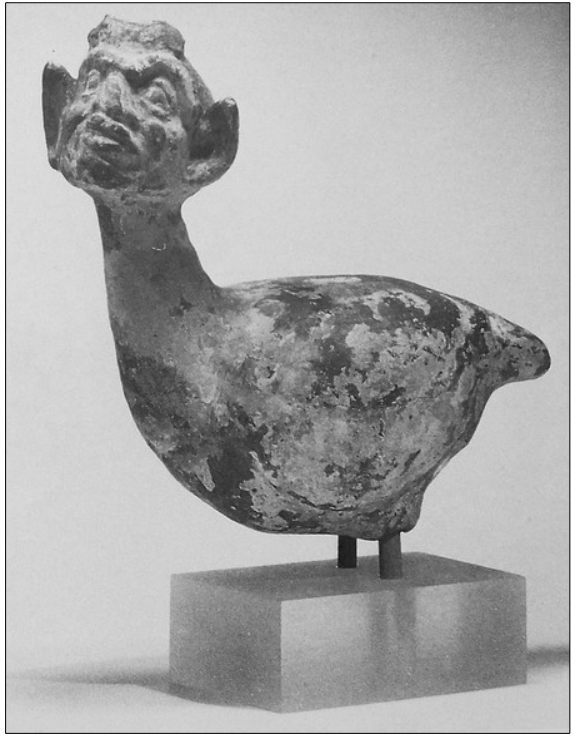

Fig.2. Hybrid creature with a male grotesque head and the body of a bird

(SchMidT 1994, pl. 47, 261).

Although the method of modelling the terracotta figurines by hand did not disappear, they were generally produced by using two-piece moulds. This, however, did not mean that the resulting products were perfectly identical to each other. After taking a semi-finished statuette out of the mould the craftsmen could still carry out minor changes with a modelling tool before firing. In fact, by attaching separately made, hand-modelled details to the moulded figurines their entire meaning could even be altered. ${ }^{5}$ For example, by adding strands of hair and a pair of earrings an old man could be transformed into an old hag (Fig. 1). The principal reason for the impossibility of a reliable reconstruction of a terracotta statuette based solely on a head fragment is, however, due to the fact that their head and body were usually made using separate part-moulds, ${ }^{6}$ thus the body parts of the different types were variable at will. ${ }^{7}$ The grotesque heads could even be placed on birds' bodies (Fig. 2) or, for example, a classical, idealised head of Herakles-type could get paired up with a distorted, hunchbacked body, as in the case of a figurine in the Boston Museum of Fine Arts. ${ }^{8}$

For all the above reasons it is not a clear-cut and solid basis for the restoration of a head fragment if we can find a parallel of the same type preserved in a more complete condition. As the vast majority of the grotesque statuette fragments in the Museum of Fine Arts, Budapest are also heads, in this article I therefore tried to collect details and attributes that may prove to be helpful in deciphering the original meaning of the figurines, even without any knowledge of the missing parts of their bodies.

4 Both in the case of terracottas from Smyrna (Higgins 1967, 110) and from Egypt (BAILEY 2008, 136).

5 Uhlenbrock 1990b, 16-17; Higgins 1967, 98-99; RoHde 1968, 11-12; Muller 1997, 445, 447-448.

6 Burn 2004, 76; Hasselin Rous et AL. 2009, 104.

7 By significantly altering certain details of an existing type - through retouching a figurine or by choosing a new combination of mould-made elements - the coroplasts would get a so-called secondary prototype that subsequently served as the starting point for a series of a new version of the original type (Muller 1997, 452).

8 Head and torso of a hunchback, Museum of Fine Arts, Boston, inv. nr. 01.7622. 


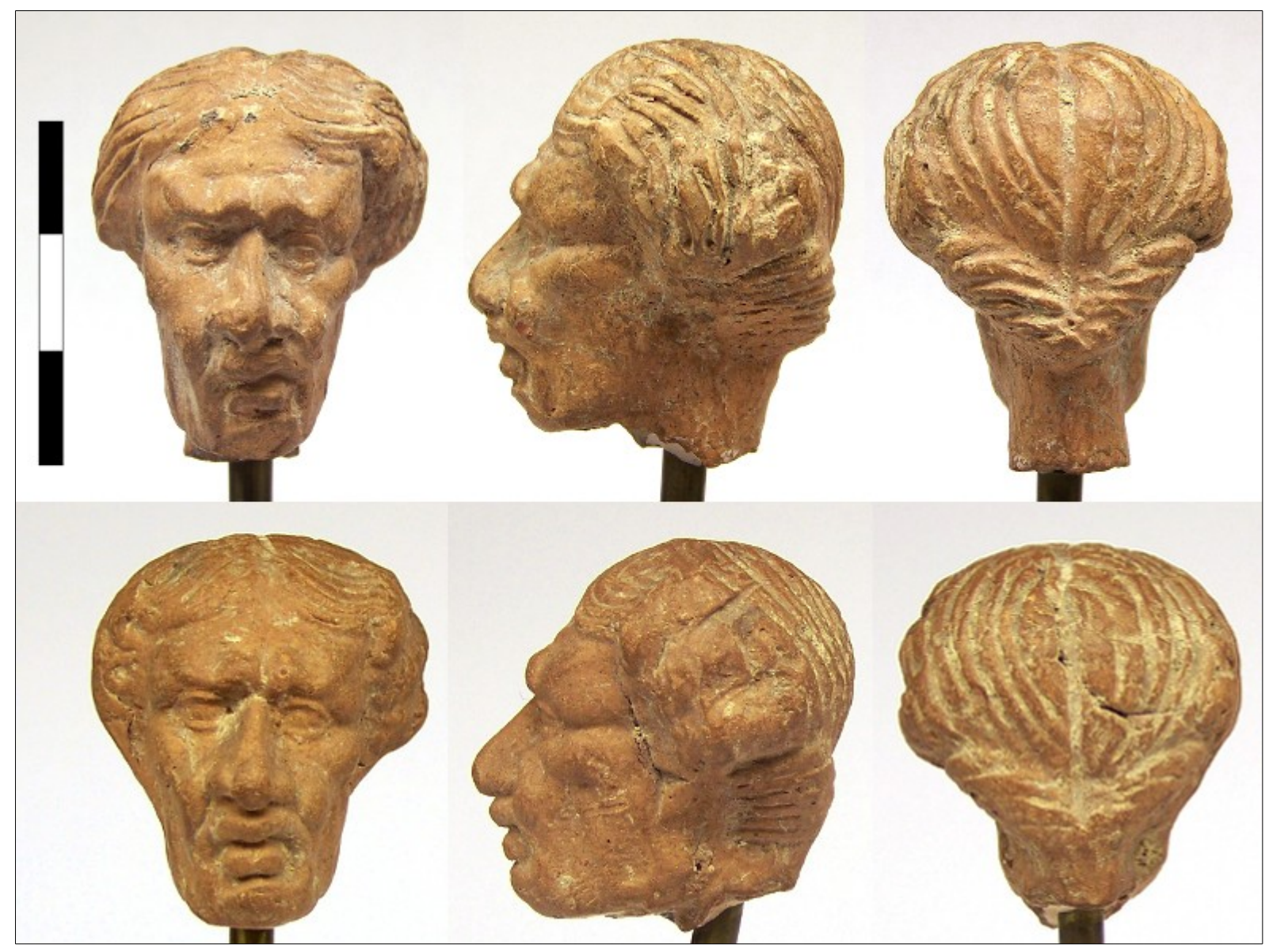

Fig.3. Two heads of old women depicted with a hairstyle characteristic of the Julio-Claudian period (inv. nr. T. 389 (above), T. 388 (below)) (Museum of Fine Arts, Budapest, photo: E. Süvegh).

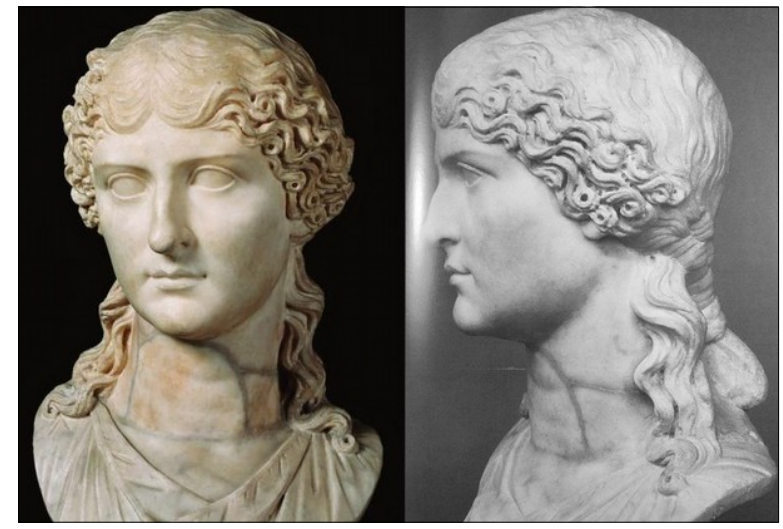

Fig.4. Marble portrait of Agrippina Maior (left) (Musei Capitolini, Rome, inv. nr. 421) (KLEINER 2010, fig. 8-9) and profile view of the same portrait (right) (Wood 1999, fig. 92).

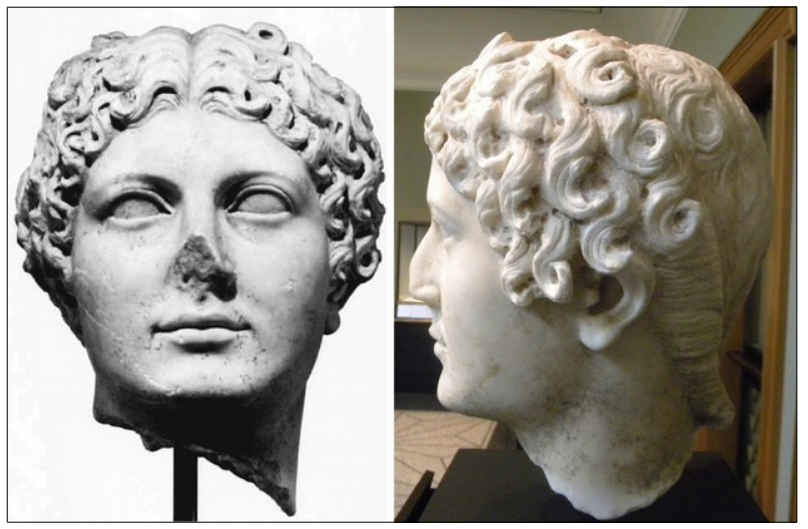

Fig.5. Marble portrait of Agrippina Minor (left) (J. Paul Getty Museum, Malibu, inv. nr. 70.AA.101) (after FrEL MoRGAN 1981, 44, nr. 29) and profile view of the same portrait (right) (Photo: Joe Geranio, https://www.flickr.com/photos/julioclaudians/8 739853966$)$. 


\section{Hairstyle and headwear}

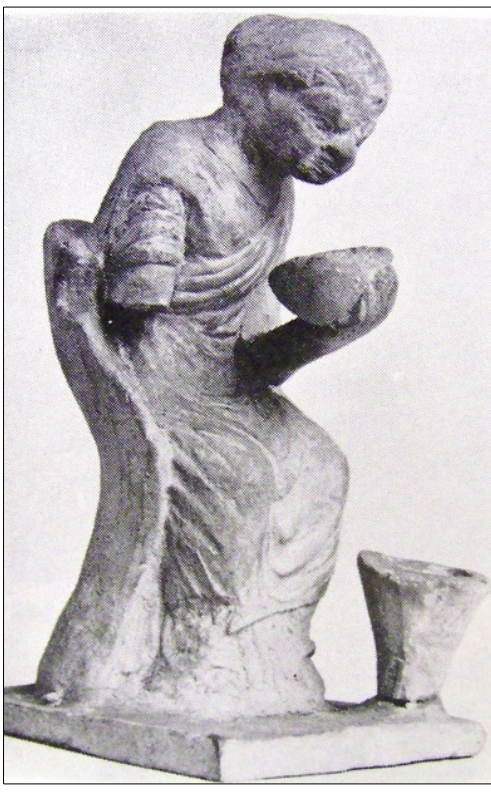

Fig.6. Figurine of an old servingwoman, (Musée du Louvre, Paris, inv. nr. CA 778) (BESQUES 1972, pl. 232 b, D 1155).
Though it is one of the typical characteristics of the grotesques that they mainly depict bald men, ${ }^{9}$ in the case of some of the rarer female heads their coiffure is also modelled in detail which can even be used as a basis for dating, however only in cases of figurines produced in the Roman period, provided that the hairstyle is comparable to one of those brought into fashion by a female member of the imperial family. ${ }^{10}$ For example, two heads of old women in the Museum of Fine Arts, Budapest (Fig. 3) based on the same prototype are modelled wearing a coiffure typical of the Principate: the hair is parted in the middle, the temples and ears are covered by curly strands, on the two sides of the neck the hair is swept back and twisted inwards, then pulled into a ponytail at the nape. Compared with examples of large-scale portrait sculpture this seems to be similar to the characteristic hairstyle of Agrippina Maior (14 BC $33 \mathrm{AD})$ (Fig. 4) ${ }^{11}$ or - as the so-called 'Korkenzieherlocken' ('corkscrew tresses') are missing - rather that of Agrippina Minor (15-59 AD) (Fig. 5). ${ }^{12}$ Thus the two terracotta fragments mentioned above can most likely be dated to the Julio-Claudian period, around the first half or the middle of the 1st century AD.

In the case of head fragments from the Hellenistic Age, instead of the coiffure different headdresses can give us some reference points regarding the identity of the depicted person.

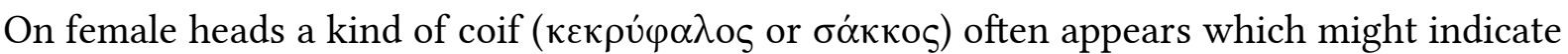
a lower social status: Ludovic Laugier suggested this connection apropos of a terracotta statuette of an old woman in the Louvre (Fig. 6) which presumably depicts an old servant wearing a chiton, himation and on her head a kekryphalos. ${ }^{13}$ There is a head fragment of a sullen old hag (Fig. 7.1) and a female torso (Fig. 7.2) in the collection of the Museum of Fine Arts, Budapest that are quite similar to the figurine discussed by Laugier, in the case of the latter a chiton and a himation worn in the same fashion can be observed. The lined face and the coif together may as well hint at an old nurse, although this headdress is a frequent but not indispensable element of the statuettes that can undoubtedly be identified as nurses. ${ }^{14}$

Among the male heads there is only one case where a kind of headwear can be reconstructed (Fig. 7.3), probably a petasos with the rim totally broken off. This, however, does not bring us closer to the identity of the figure, as the petasos was a part of both men's and women's everyday wear: it was mainly worn by those who spent much time outdoors, such as fishermen, shepherds, travellers (Fig. 8.) and hunters, but epheboi are also shown wearing this type of hat in Greek art. ${ }^{15}$

9 Oroszlán 1930, 77.

10 Mitchell 2013, 275-276.

11 Giroire - Roger 2007, 73.

12 Frel - Morgan 1981, 45.

13 Hasselin Rous et AL. 2009, 189, nr. 110.

14 SCHulze 1998, 42, 52

15 Hurschmann 2000. 


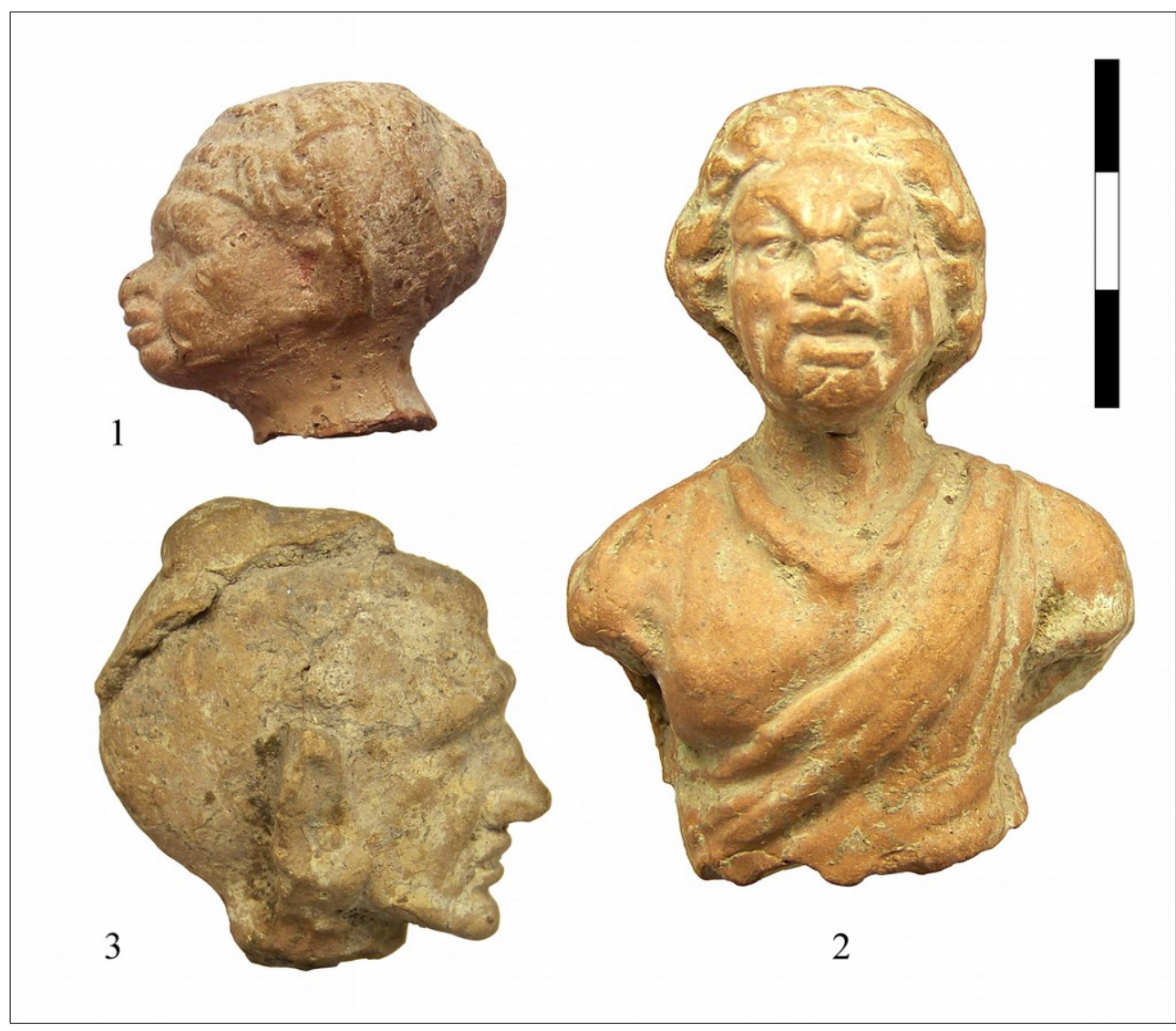

Fig.7. 1. Head of an old woman wearing a kekryphalos (inv. nr. T.432). 2. Head and torso of an old woman, wearing a kekryphalos, chiton and himation (inv. nr. T.438). 3. Head of a man wearing a hat (rim broken off) (inv. nr. T.408) (Museum of Fine Arts, Budapest, photo: E. Süvegh).

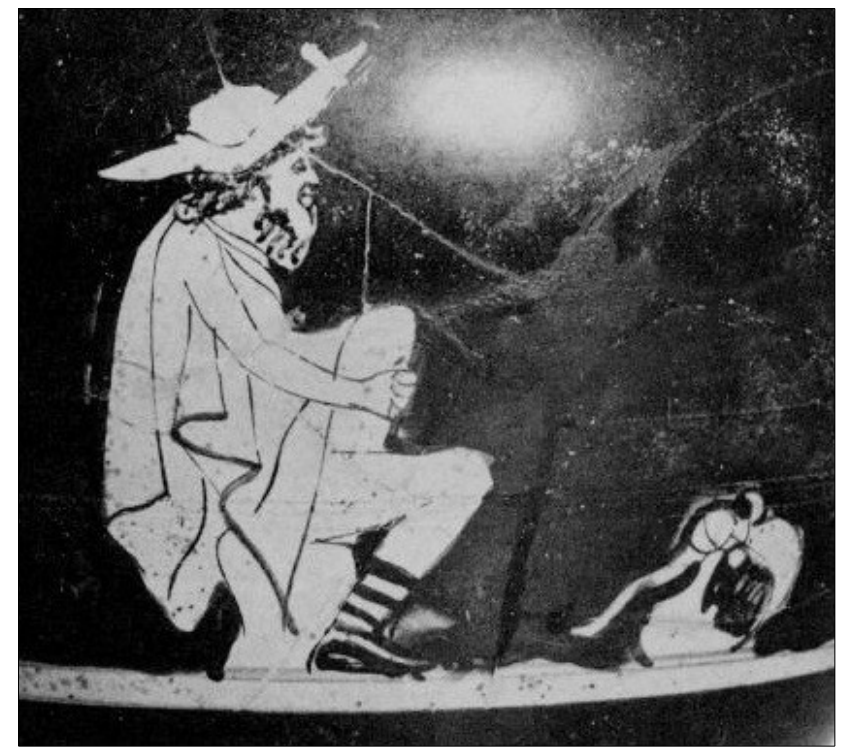

Fig.8. Traveller wearing a petasos. Attic red-figure oinochoe, ca. 470-460 BC (after RoBInson 1937, pl. (281) 38.3).

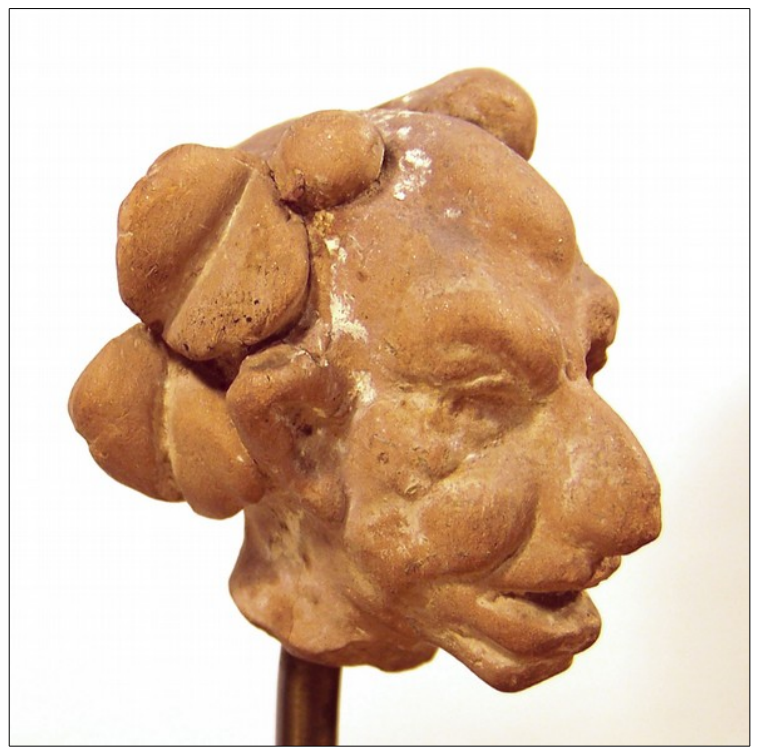

Fig.9. Head of a man wearing a wreath made of leaves and berries (inv. nr. T.395) (Museum of Fine Arts, Budapest, photo: E. Süvegh). 


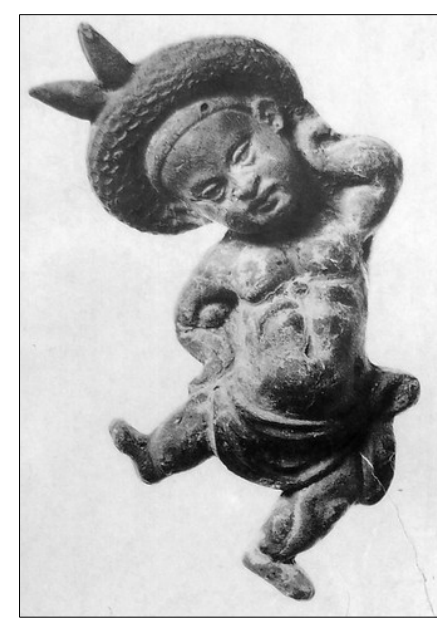

Fig. 10. Figurine of a dancing dwarf wearing a wreath (Fischer 1994, cover image).

Wreaths also often appear on these grotesque heads. ${ }^{16}$ They either consist of a ribbon with leaves, flowers and berries attached to it (Fig. 9), or they are modelled in the form of a roll sometimes bound with a flat band (Fig. 10). These figures are conventionally interpreted as participants of different religious festivals, especially those intact statuettes which,judged by their gestures, seem to be dancing or also holding musical instruments in their hands,

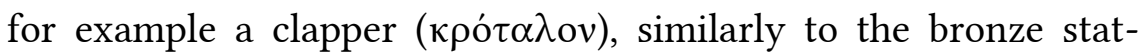
uettes of dancing dwarfs from the Mahdia shipwreck. These terracotta figurines are suggested to be linked to festivals, especially those honouring Dionysos, the Egyptian Lagynophoria for instance: the Ptolemies who introduced this festival attached great importance to this deity in their royal propaganda. ${ }^{17}$ Wreaths also frequently appear as part of the costume of actors, besides they also have a close connection to the symposion, ${ }^{18}$ where the guests and also the musicians, dancers and other entertainers often wore wreaths: it is possible that the grotesque dancing dwarfs were intended to depict such entertainers. ${ }^{19}$

\section{Ethnic types}

In catalogues of Greek and Roman terracottas sometimes we come across comments concerning the ethnicity of a male or female figure, suggesting that some statuettes show ethnic groups different from the ancient Greeks: I aimed at investigating the validity of this assumption in my bachelor's thesis. In my opinion, most of all the negroid features characteristic of Africans can be identified on certain terracottas, sometimes with certainty (Fig. 11), in other cases less convincingly (Fig. 12.1). ${ }^{20}$

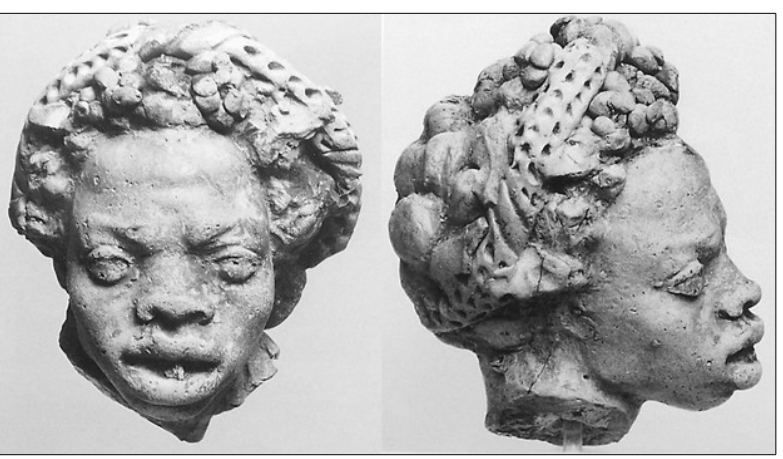

Fig.11. Head of an African. From Priene (Rumscheid 2006, pl. 125.1, 3, cat. nr. 288).

Another ethnic type often mentioned consists of heads allegedly showing characteristic 'Semitic' or 'Syrian' features (Fig. 12.2). ${ }^{21}$ The head fragments in this group basically share one common facial feature: the large, hooked, long, protruding nose which in my view cannot be considered an explicit trait referring to ethnicity, since it can also be explained in other ways. ${ }^{22}$ Rather this notion may bear testimony to the direction of scientific research in the 19th and early 20th centuries as in physical anthropology this nose shape was considered

16 BurN - Higgins 2001, 128.

17 Fischer 1994, 52, 70-71; TÖrÖK 1995, 21; Wrede 1988; SEILER 2011, 16, 22.

18 The symposion does have a connection to the previously mentioned religious festivals, however, as this form of gathering was a common part of numerous kinds of different festivities (BLECH 1982, 63).

19 Blech 1982, 63-64; Laubscher 1982, 70; Giuliani 1987, 712-713; Uhlenbrock 1990c, 77.

20 BURN 2004, 75-76.

21 Two examples from the catalogue of terracottas in the Museum of Fine Arts, Budapest are inv. nr. T.391 (OroszLÁN 1930, 79, E20: 'its Syrian character is conspicuous') and inv. nr. T.400 (Oroszlán 1930, 79, E26: 'strong Semitic character').

22 For the connection of the hooked nose shape to the comic theatre and certain medical conditions, see the discussion of a figurine in the Louvre by Laugier (HASSELIN Rous ET AL. 2009, 180, nr. 97). 
to be specifically characteristic of Jews or the peoples living in Syria in general. ${ }^{23}$ It is possible that part of the terracotta figurines was intended to depict members of different folks in termingled in a Hellenistic metropolis, but these are certainly more difficult to identify than the statuettes of Africans.

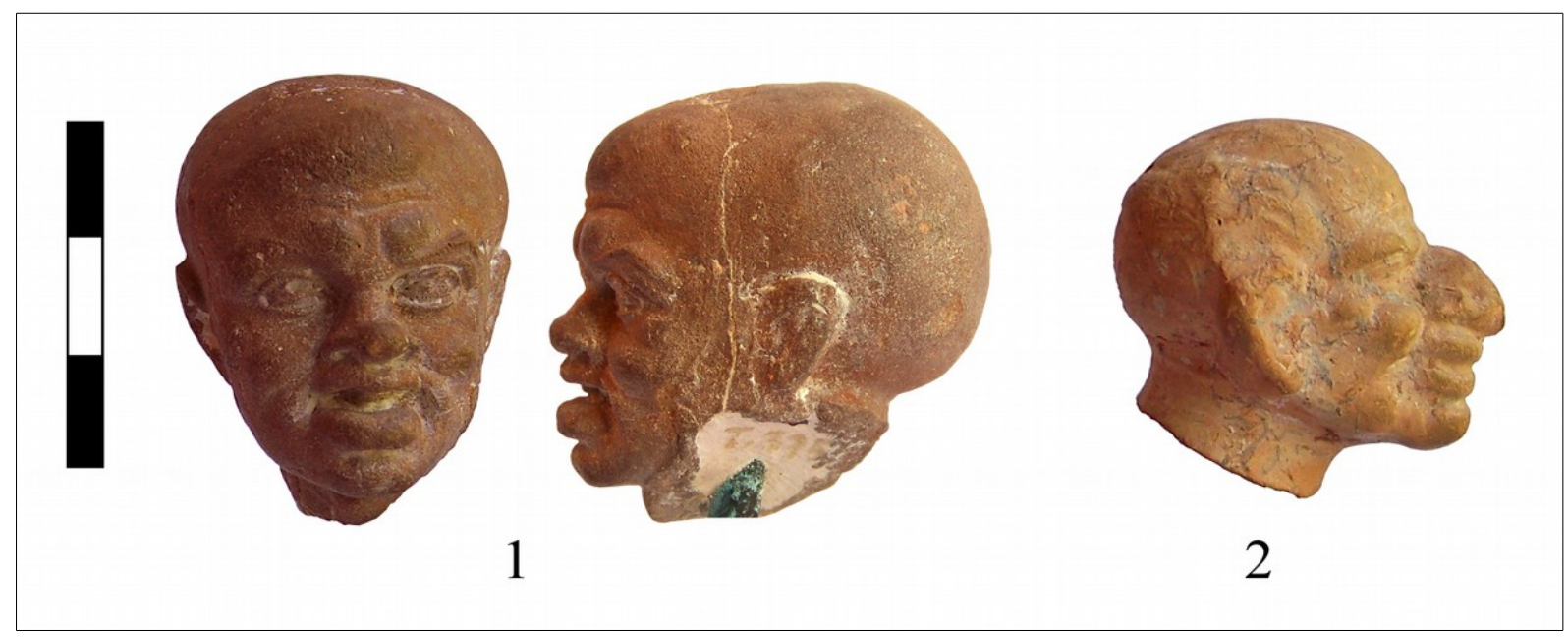

Fig.12. 1. Head of a bald man (inv. nr. T.375). 2. Head of a balding elderly man (inv. nr. T.391) (Museum of Fine Arts, Budapest, photo: E. Süvegh).

\section{Diseases and characteristic injuries}

The so-called pathological grotesques show men and women suffering from illnesses: they are quite accurate representations of different diseases. ${ }^{24}$ However, according to scholars with medical expertise it is possible to recognize any symptom only in the case of fully intact figurines, with the torso also preserved. Therefore we must treat any kind of medical diagnosis with reservations, especially if it has been based on a head fragment broken from a now missing body. ${ }^{25}$

According to a theory slitted or closed eyes were meant to signify blindness: ${ }^{26}$ we can see such eyes, swollen and narrowing to slits on one of the heads showing old women wearing coifs in the Museum of Fine Arts, Budapest (Fig. 13.1). A feature of another head fragment from the collection that of a bald man (Fig. 13.2) also hint at illness, more specifically malnutrition: he is shown with a bony, protruding larynx modelled quite similarly to the sharp protrusions of the vertebrae along the spine of hunch-backed or emaciated figurines.

Though dwarfism can primarily be recognised by noting that the head of a person is too big compared to the body, or that the limbs are disproportionately short, ${ }^{27}$ a certain type of this condition called achondroplasia also affects the shape of the head and some facial features. The result is a characteristic look that we can examine on the separate terracotta head frag ments as well: there are protrusions on the forehead and on the two sides of the skull on the parietal bones, the nasal bridge is pronouncedly flattened, the nose is upturned and the tip of the nose is fleshy. ${ }^{28}$

23 JABET 1848, 156-157.

24 See further, Stevenson 1975; Garland 1995; GrmeK-Gourevich 1998; most recently, Mitchell 2013.

25 HolläNDER 1912, 332; STEVENSON 1975, 104

26 GARLAND 1995, 112.

27 Wrede 1988, 98; Garland 1995, 116; Fisher 1994, 51, note 3.

28 IANNOTTI - PARKER 2013, 120. 


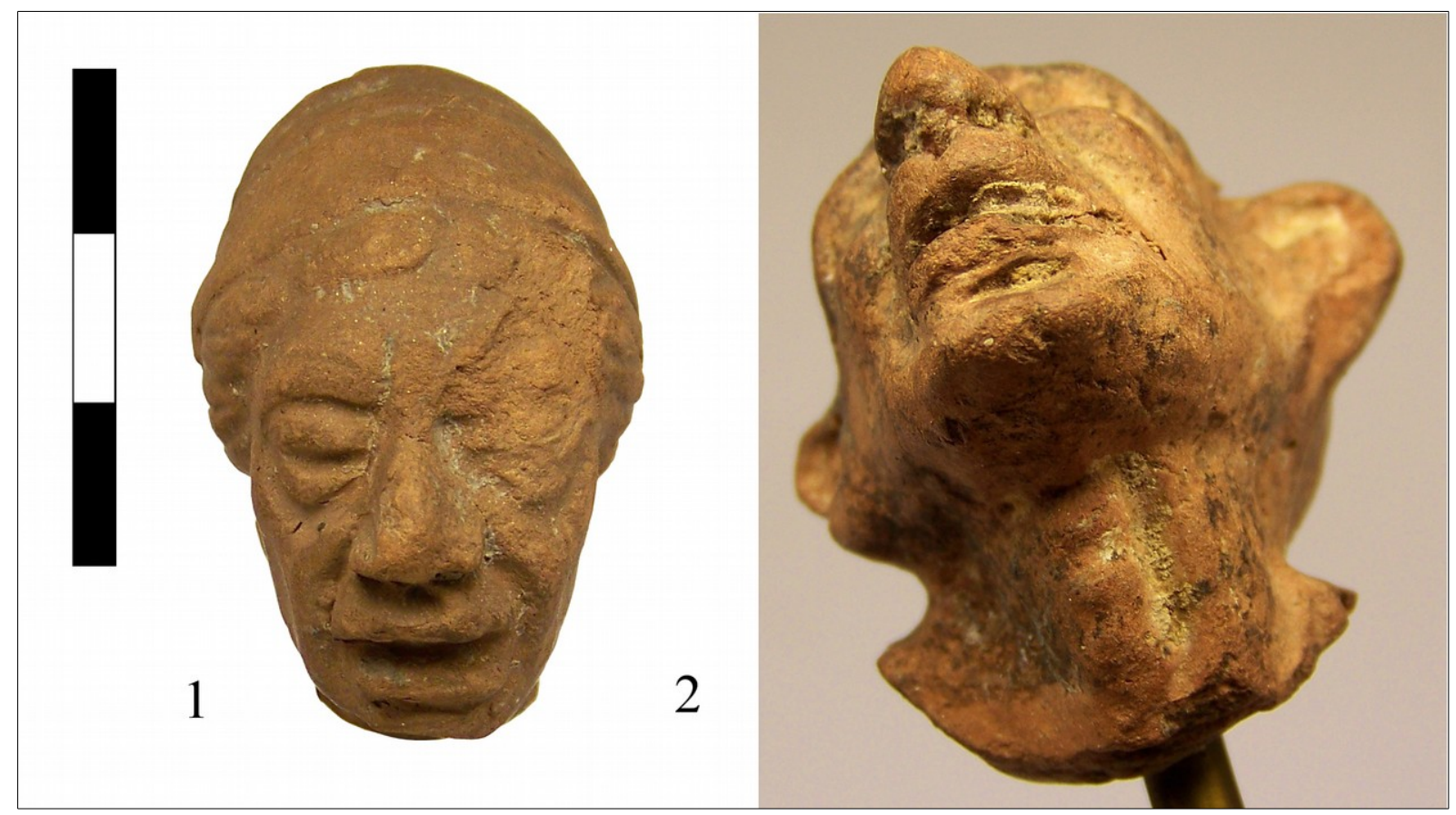

Fig.13. 1. Head of an old woman depicted with her eyes closed (inv. nr. T.425) 2. Protruding, bony larynx of a bald male figure (inv. nr. T.397) (not to scale) (Museum of Fine Arts, Budapest, photo: E. Süvegh).

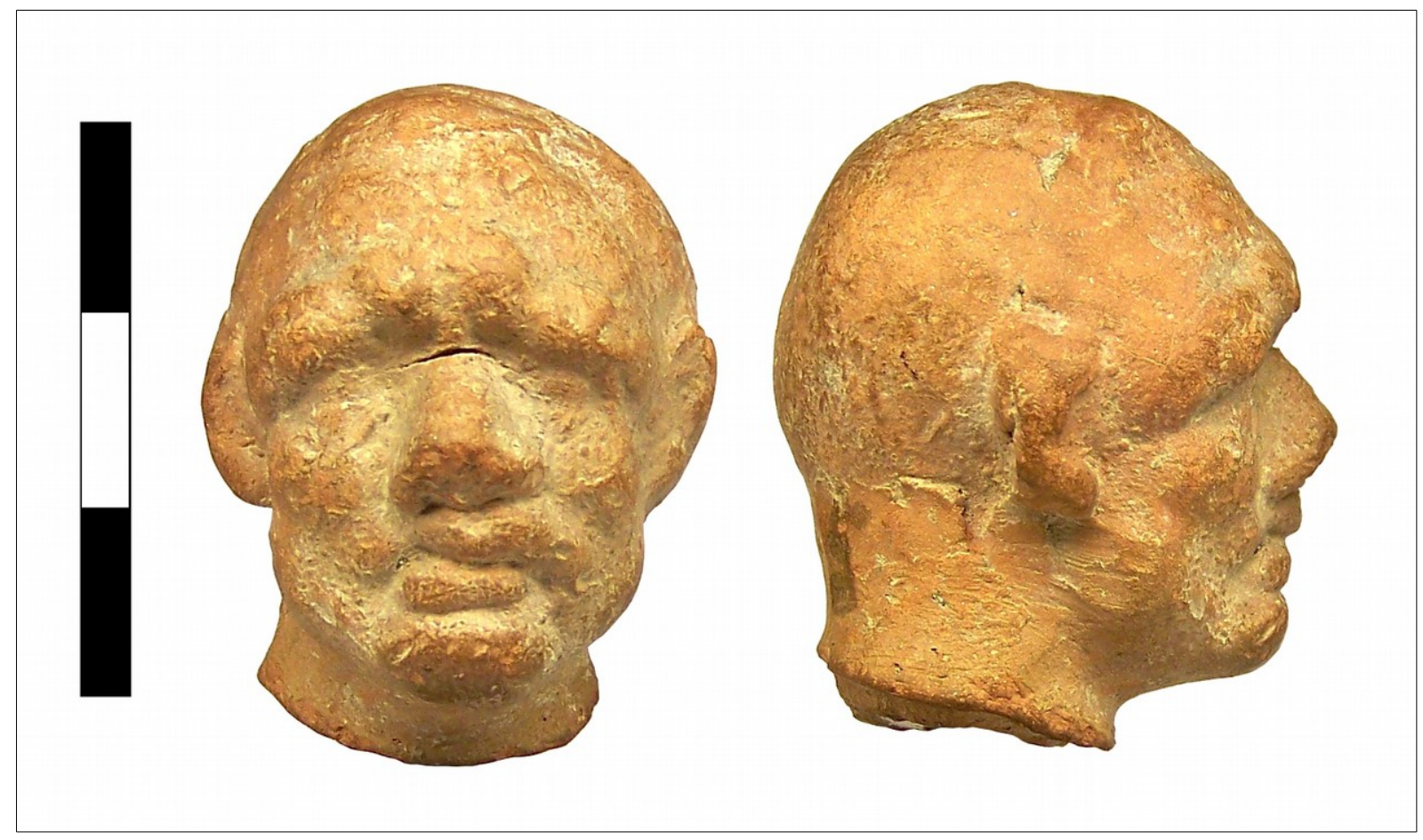

Fig.14. Head of a bald man, possibly a boxer (inv. nr. T.421) (Museum of Fine Arts, Budapest, photo: E. Süvegh). 


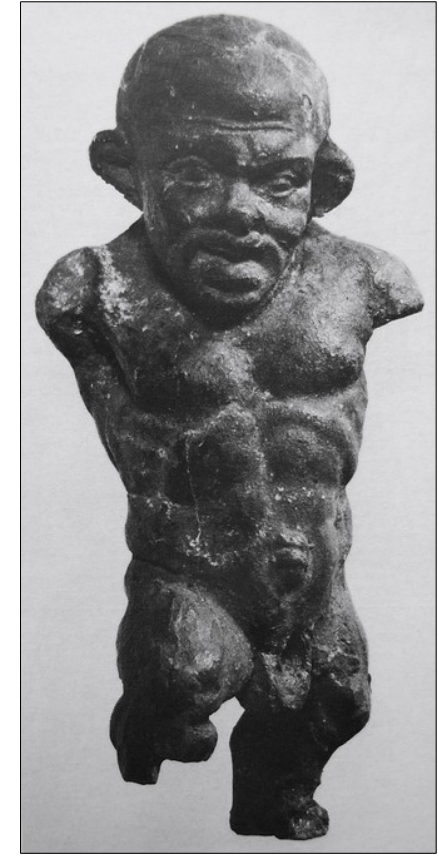

Fig.15. Figurine of a dwarf (Allard Pierson Museum, Amsterdam, inv. nr. 7135) (LuNSINGH SCHEURLEER 1986, 92, nr. 100).
A male head with full lips and flat nose (Fig. 12.1) which at first glance seems to have belonged to an African shows all the aforementioned features, and although László Török rejected the pathological interpretation of this fragment, ${ }^{29}$ I still deem it possible that the head once belonged to the statuette of an achondroplastic dwarf. This possibility can be supported by a dwarf figurine in Amsterdam (Fig. 15): its head can definitely be traced back to the same prototype as the head fragment in Budapest, yet it has to be mentioned that also in this case head and body were made from separate part-moulds.

Beside the symptoms of diseases scholars have also tried to identify characteristic injuries on certain grotesque heads, like the typical, swollen cauliflower ears and broken nose of boxers. ${ }^{30}$ There are examples of these features among the head fragments in the Museum of Fine Arts as well (Fig. 14). ${ }^{31}$ However, based on the known intact figurines undoubtedly depicting boxers ${ }^{32}$ we can state that in the case of small terracotta statuettes the craftsmen did not always take care of forming these tiny details, ${ }^{33}$ contrary to such richly detailed large bronze sculptures as the famous Thermae boxer (Fig. 16). The so-called i $\mu \alpha{ }^{\prime} \nu \tau \varepsilon \varsigma$, the bandages or 'boxing gloves' made of leather strips worn on the hands of Greek boxers represent more unambiguous attributes. ${ }^{34}$

\section{The grotesques and New Comedy}

It is a widely accepted opinion that many of the Hellenistic grotesque statuettes are principally connected to the sphere of the theatre and they might depict the actors of New Comedy. ${ }^{35}$ Here I give two examples for head fragments comparable to one or another mask type of New Comedy from the Collection of Classical Antiquities of the $\mathrm{Mu}$ seum of Fine Arts, Budapest. The torso of an old woman already mentioned earlier (Fig. 7.2) - with her curly hair without a parting, sunken cheeks, lined face, stylised, 'hooked', knitted brows and snub nose - looks very similar to the mask of one

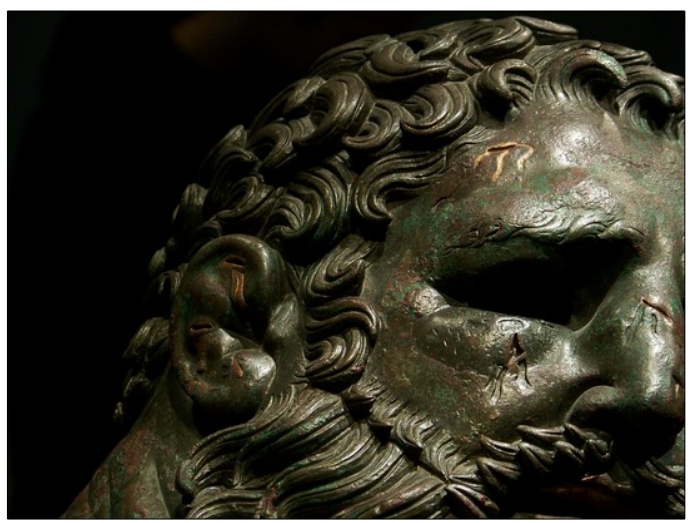

Fig.16. Detail of the so-called 'Thermae boxer' (Museo Nazionale Romano, Palazzo Massimo alle Terme, Rome, inv. nr. 1055, photo: E. Süvegh).

29 TöRÖк 1995, 157-158, nr. 241.

30 Two examples of head fragments identified as those of boxers: Musée du Louvre, Paris, inv. nr. CA 292 (1889) (BEsQuEs 1972, pl. 189 d, E/D 1039); Liebieghaus Skulpturensammlung, Frankfurt am Main, inv. nr. 2400.1563 (BAYER-NIEMEIER 1988, Kat-Nr. 480, Taf. 87.2).

31 Museum of Fine Arts, Budapest, inv. nr. T.421, T.376, maybe also T.381.

32 Two examples of (nearly) intact figurines of boxers: Musée du Louvre, Paris, inv. nr. CA 1608 (HAssELIN Rous ET AL. 2009, 182, nr. 99); a figurine of a boxer from the collection of Shelby White and Leon Levy, New York (UHLENBRock 1990 a, 146, cat. nr. 33).

33 For example, neither of the pair of African boxers in the British Museum shows any sign of head injuries (British Mu seum, London, 1852,0401.1-2).

34 Mitchell 2013, 280-281; UhlenBRock 1990a, 146.

35 Higgins 1967, 112; Mitchell 2013, 275, 277-278; Garland 1995, 110. 


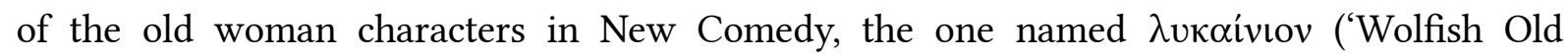
Woman') ${ }^{36}$ in Iulius Pollux's Onomasticon (Pollux, Onomasticon 4.150). Another mask type, the

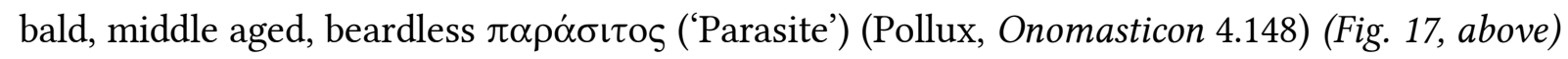
with its hooked nose and slightly knitted brows shows a close resemblance to the features of the male head shown in Fig. 17 (below). ${ }^{37}$

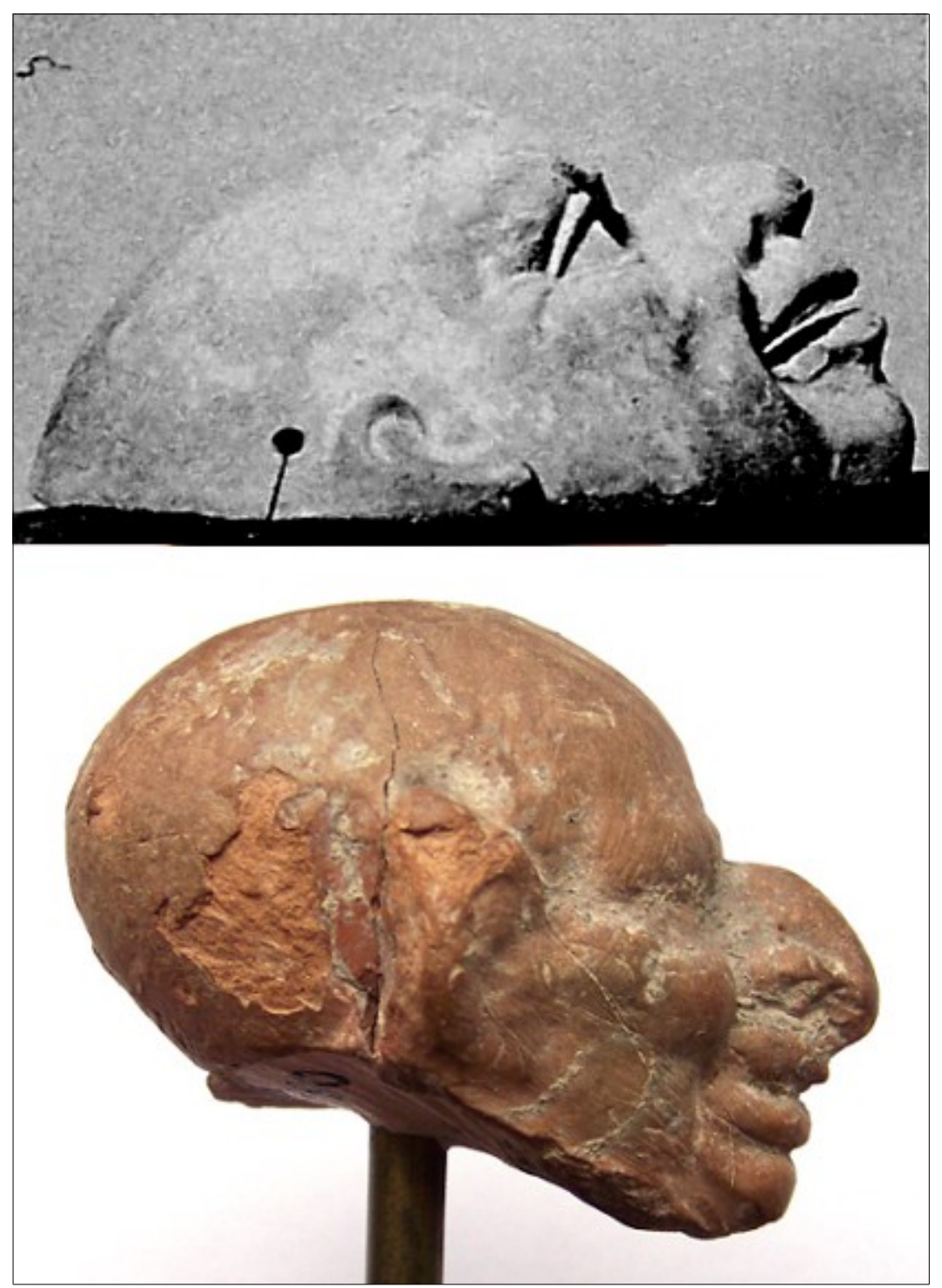

Fig.17. Terracotta mask of the 'Parasite' character of New Comedy (above) (BIEBER 1961, 100, fig. 373 a (rotated)) and head fragment of a terracotta figurine with similar features (below) (inv. nr. T.390) (Museum of Fine Arts, Budapest, photo: E. Süvegh).

However, because the plays of New Comedy mostly drew their themes from daily life and the costumes of the actors were close to regular everyday clothes, further, the disproportionately large size of theatrical masks was reduced compared to earlier types, it is difficult for us to establish whether the terracotta statuettes depict an actor wearing a mask, or we are simply dealing with a genre figure. ${ }^{38}$ 
Finally I wish to present a head fragment with quite an unusual facial expression (Fig. 18) which led me to suggest a certain interpretation of the original statuette, although it is a rather speculative assumption, and its correctness cannot be proven beyond doubt. The bald male head has on the one hand enormous, bulging, puffed up cheeks, which the coroplast atttached to the face after moulding, on the other hand the strange lips are also hand-modelled: they are flat, protruding like a beak, pointed in the middle where they meet, while on the two sides they are parted. I deem it possible that the figure originally held one mouthpiece of a

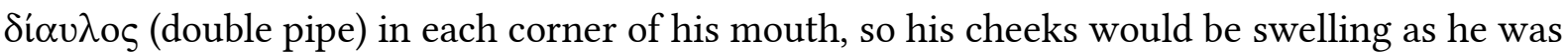
blowing the instrument, much like in the case of diaulos players on vase paintings (Fig. 19). I have to point out though that I have not been able to observe any fragments or traces in the mouth that could be identified as the remains of such mouthpieces. The only terracotta figurine known to me this far which shows a diaulos player with her mouth formed similarly (Fig. 20, left), is depicted with the pipes pressed close to her chest, while in the case of the head in Budapest the musician would probably have held his instruments off his body. However, through another statuette playing the double pipe (Fig. 20, right) it can at least be proven that modelling such a figurine was technically possible, although its protruding parts could have been vulnerable.

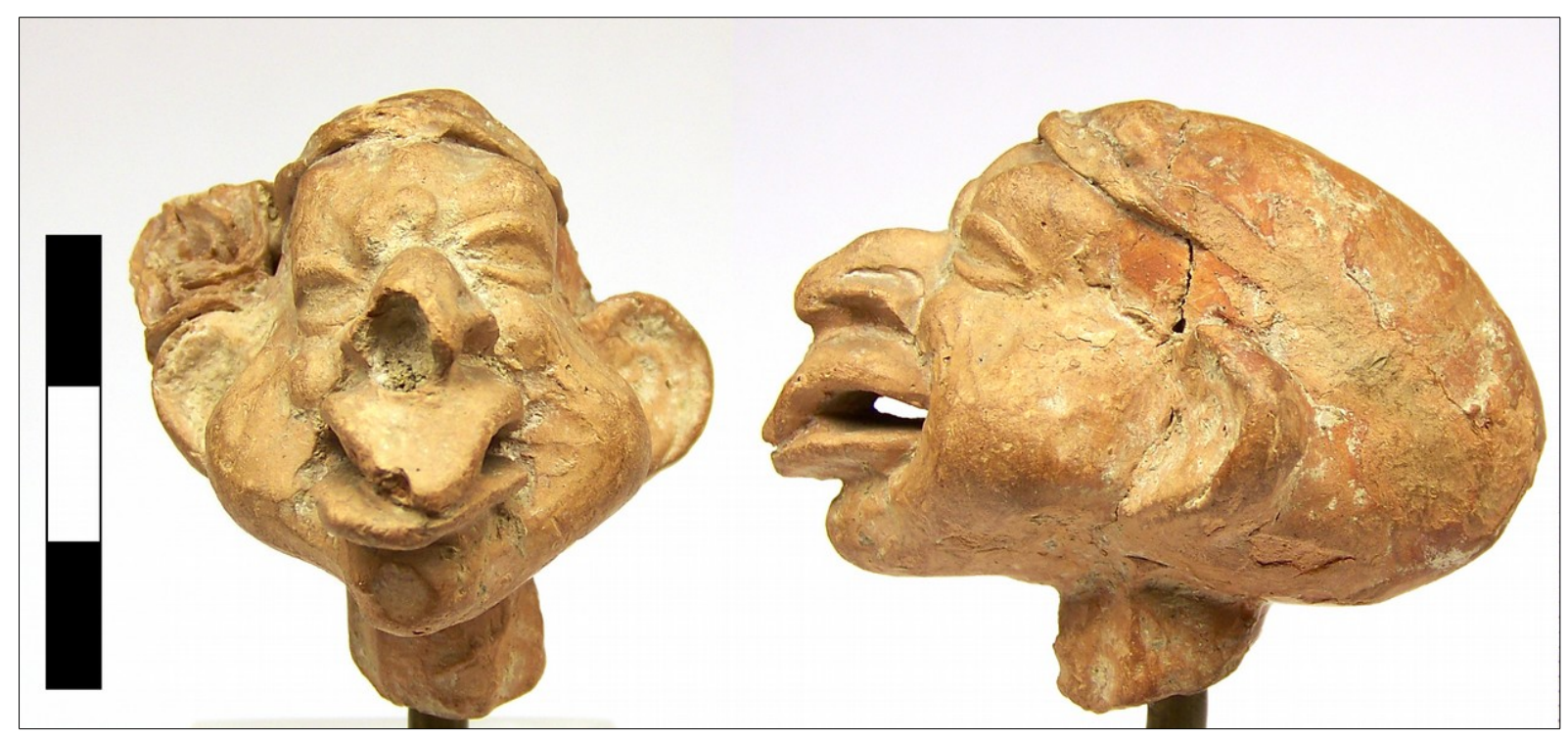

Fig.18. Head of a bald man wearing a ribbon and a flower behind his ear (inv. nr. T.392) (Museum of Fine Arts, Budapest, photo: E. Süvegh).

In conclusion, it can be stated that it is not impossible to approximately define the iconographical type of a statuette based solely on a head fragment. However, the results received this way are inevitably uncertain. In addition, it is essential that we rely on intact or more complete figurines, typological parallels when attempting to interpret the head fragments, on the stipulation that we have to bear in mind the limitations of one-to-one correspondence mentioned earlier. 


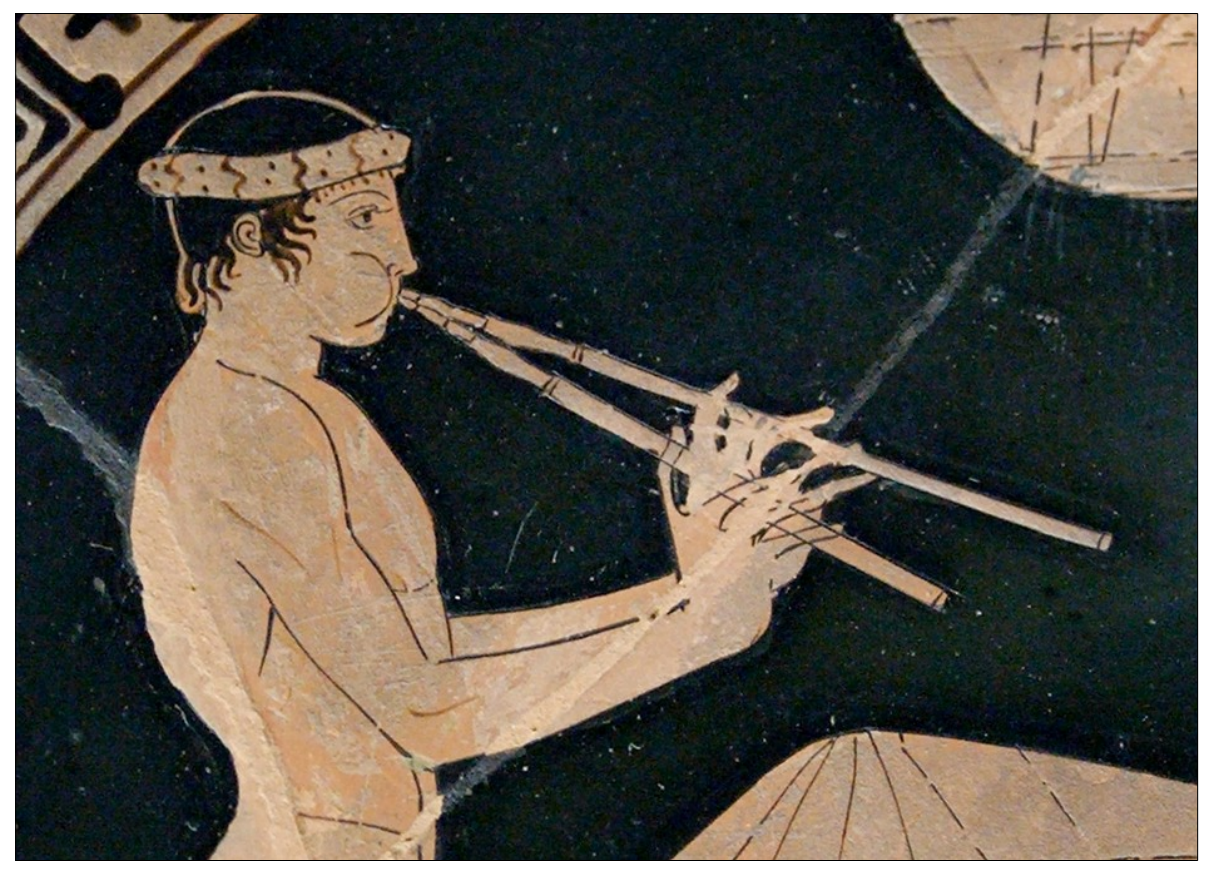

Fig.19. Youth playing the diaulos. Tondo of an Attic red-figure cup by the Euaion Painter (detail), about 460 BC-450 BC (Musée du Louvre, Paris, inv. nr. G 467) (Photo @ Marie-Lan Nguyen/ Wikimedia Commons, http://commons.wikimedia.org/wiki/File:Banquet_Euaion_Louvre_G467_n2.jpg).

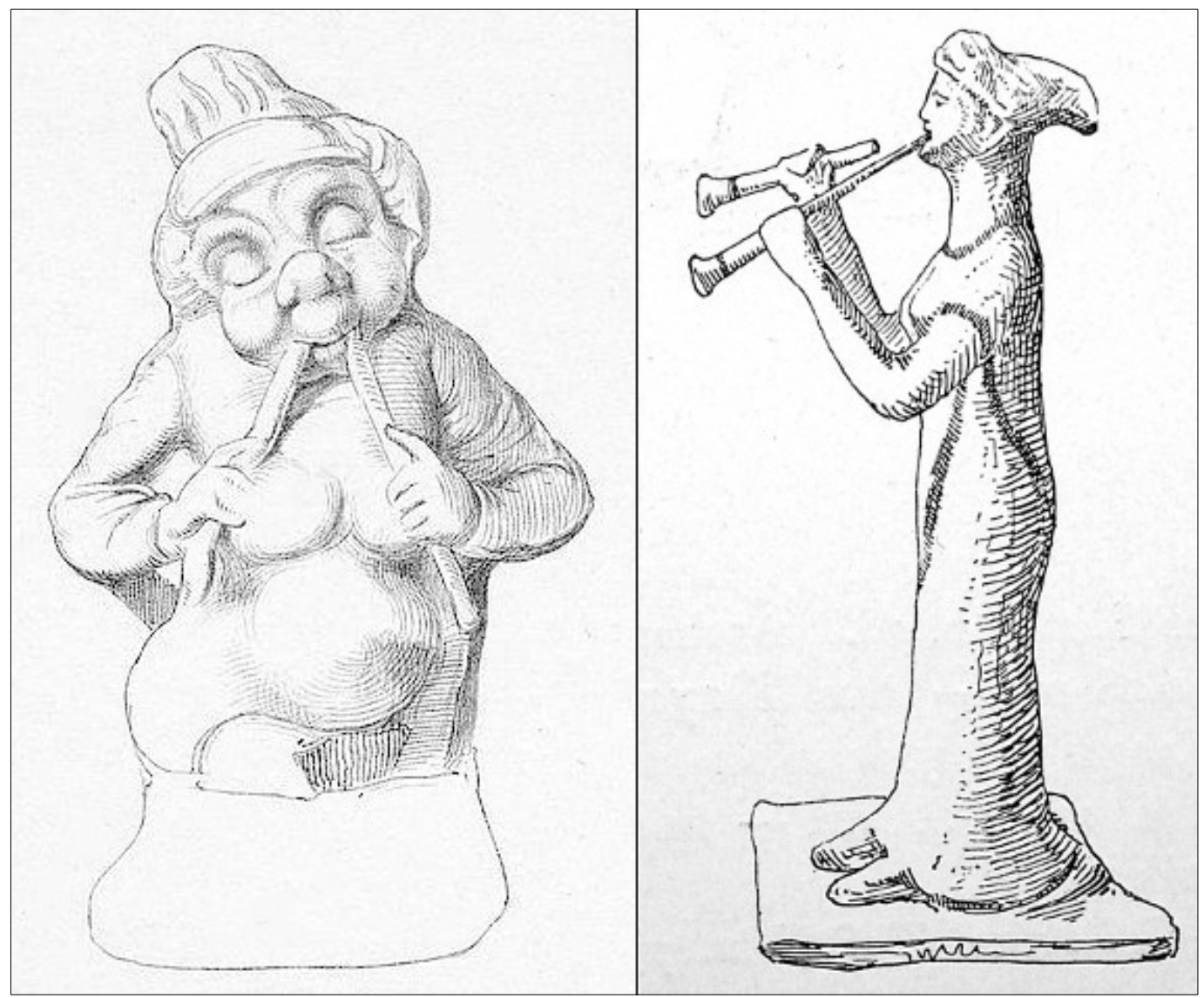

Fig.20. Two figurines of female diaulos players

(Left: SchÖNE 1872, pl. 36, nr. 139; right: WINTER 1903, 33, nr. 11). 


\section{References}

BAILEy, D.M. 2008: Catalogue of terracottas in the British Museum. Vol. IV: Ptolemaic and Roman terracottas from Egypt. London.

BAyer-Niemeier, E. 1988: Griechisch-römische Terrakotten, Liebieghaus-Museum Alter Plastik, Bildwerke der Sammlung Kaufmann. Band 1. Melsungen.

BESQues, S. 1972: Catalogue raisonné des figurines et reliefs en terre-cuite grecs, étrusques et romains. Vol. III. Paris.

Bieber, M. 1961: The history of the Greek and Roman theatre. Princetone, New Yersey.

Blech, M. 1982: Studien zum Kranz bei den Griechen. Berlin-New York.

Burn, L. 2004: Hellenistic art: From Alexander the Great to Augustus. London.

Burn, L. - Higgins, R.A. 2001: Catalogue of terracottas in the British Museum. Vol. III. London.

Fischer, J. 1994: Griechisch-römische Terrakotten aus Ägypten: Die Sammlungen Sieglin und Schreiber. Dresden, Leipzig, Stuttgart, Tübingen. Tübinger Studien zur Archäologie und Kunstgeschichte 14. Tübingen.

Frel, J. - Morgan, S.K. 1981: Roman portraits in the f. Paul Getty Museum. Tulsa.

GARLAND, R. 1995: The eye of the beholder: Deformity and disability in the Graeco-Roman world. Ithaca (N.Y.).

Giroire, C. - Roger, D. 2007: Roman art from the Louvre. New York.

Givliani, L. 1987: Die seligen Krüppel: Zum Deutung von Missgestalten in der hellenistischen Kleinkunst. Archäologischer Anzeiger 102, 701-721.

Grmek, M. - Gourevich, D. 1998: Les maladies dans l'art antique, Paris.

Hasselin Rous, I. - Martinez, J.-L. - Laugier, L. (eds.) 2009: D'Izmir à Smyrne: Découverte d'une cité antique. Paris.

Higgins, R.A. 1967: Greek terracottas. London.

Holländer, E. 1912: Plastik und Medizin. Stuttgart.

Hurschmann, R. 2000: s.v. Petasos. In: Cancik, H. - Schneider, H. (eds.): Der Neue Pauly: Enzyklopädie der Antike: Altertum. Band 9: Or-Poi. Weimar-Stuttgart, 660.

IAnNotti, J.P. - Parker, R.D. 2013: The Netter Collection of Medical Illustrations. Vol. 6: Musculoskeletal system. Part III: Biology and systemic diseases. Philadelphia.

JABET, G. 1848: Nasology: Or, hints towards a classification of noses. London.

KLEINER, F.S. 2010: A history of Roman art: Enhanced edition. Boston.

LAUbSCher, H.P. 1982: Fischer und Landleute: Studien zur hellenistischen Genreplastik. Mainz am Rhein.

Lunsingh ScheurleER, R.A. 1986: Grieken in het klein: 100 antieke terracotta's. Amsterdam.

Mrtchell, A.G. 2013: Disparate bodies in ancient artefacts: The function of caricature and pathological grotesques among Roman terracotta figurines. In: LAES, Ch. et al. (eds.): Disabilities in Roman antiquity: Disparate bodies a capite ad calcem. Leiden-Boston, 275-297.

Muller, A. 1997: Description et analyse des productions moulées: Proposition de lexique multilingue, suggestions de méthode. In: Muller, A. (ed.): Le moulage en terre cuite dans l'antiquité: Création et production dérivée, fabrication et diffusion. Actes du XVIIIe Colloque du Centre de Recherches Archéologiques - Lille III (7-8 déc. 1995), Villeneuve d'Ascq, 437-463. 
Oroszlán Z. 1930: Az Országos Magyar Szépmúvészeti Múzeum antik terrakotta gyüjteményének katalógusa. Budapest.

Robinson, D.M. 1937: Corpus Vasorum Antiquorum. United States of America. Fascicule 6: The Robinson Collection, Baltimore, MD. Fascicule 2. Cambridge, Mass.

RoHDE, E. 1968: Griechische Terrakotten. Tübingen.

Rumscheid, F. 2006: Die figürlichen Terrakotten von Pirene: Fundkontexte, Ikonographie und Funktion im Wohnhäusern und Heiligtümern im Licht antiker Paralellbefunde. Archäologische Forschungen 22: Priene 1. Wiesbaden.

Schмidt, E. 1994: Katalog der antiken Terrakotten. Teil 1: Die figürlichen Terrakotten. Mainz am Rhein.

SснӧNE, R. (ed.) 1872: Griechische Reliefs aus athenische Sammlungen. Leipzig.

Schulze, H. 1998: Ammen und Pädagogen: Sklavinnen und Sklaven als Erzieher in der antiken Kunst und Gesellschaft. Mainz am Rhein.

SeILeR, S. (ed.) 2011: Armut in der Antike: Perspektiven in Kunst und Gesellschaft. Begleitheft zur Sonderausstellung. Schriftenreihe des Rheinischen Landesmuseums Trier 37. Trier.

Stevenson, W. 1975: The representation of the pathological grotesque in Greek and Roman art. Unpublished diss., University of Pennsylvania.

Тӧвӧк, L. 1995: Hellenistic and Roman terracottas from Egypt. Roma.

UhlenBrock, J.P. (ed.) 1990a: The coroplast's art: Greek terracottas of the Hellenistic world. New York.

UhlenBrock, J.P. 1990b: The coroplast and his craft. In: UhlenBrock, J.P. (ed.) 1990a: The coroplast's art: Greek terracottas of the Hellenistic world. New York, 15-21.

Uhlenвrock, J.P. 1990c: East Greek coroplastic centers in the Hellenistic period. In: Uhlenbrock, J.P. (ed.) 1990a: The coroplast's art: Greek terracottas of the Hellenistic world. New York, 72-80.

Webster, T.B.L. 1995: Monuments illustrating New Comedy. London.

WinTER, F. 1903: Die antiken Terrakotten. Band III, Teil 1: Die Typen der figürlichen Terrakotten. BerlinStuttgart.

Wood, S.E. 1999: Imperial women. Leiden.

WrEDE, H. 1988: Die tanzenden Musikanten von Mahdia und der alexandrinische Götter- und Herrscherkult. Mitteilungen des Deutschen Archäologischen Instituts, Römische Abteilung 95, 97-114. 